\title{
SYNTHESIS OF $\mathrm{Pb}_{2} \mathrm{Fe}_{2} \mathrm{O}_{5}$ BY THERMAL DECOMPOSITION OF Pb $2\left[\mathrm{Fe}(\mathrm{CN})_{6}\right] \cdot 4 \mathrm{H}_{2} \mathrm{O}$
}

\author{
DIEGO MAURICIO GIL ${ }^{a}$, RAÚL E. CARBONIO ${ }^{b}$ AND MARÍA INÉS GÓMEZ ${ }^{a^{*}}$ \\ ${ }^{a}$ Instituto de Química Inorgánica; Facultad de Bioquímica, Química y Farmacia; Universidad Nacional de Tucumán. \\ Ayacucho 471. 4000. San Miguel de Tucumán. Argentina. \\ ${ }^{b}$ Instituto de Investigaciones en Fisicoquímica de Córdoba (INFIQC). Departamento de Fisicoquímica; Facultad de Ciencias Químicas; \\ Universidad Nacional de Córdoba. Ciudad Universitaria. 5000. Córdoba. Argentina.
}

(Received: May 12, 2009 - Accepted: April 7, 2010)

\begin{abstract}
In the present work the synthesis, thermal analysis and structural characterization of $\mathrm{Pb}_{2}\left[\mathrm{Fe}(\mathrm{CN})_{6}\right] .4 \mathrm{H}_{2} \mathrm{O}$ are described in order to obtain mixed oxides with technological properties. The starting materials and the decomposition products were characterized by IR spectroscopy, powder X-ray diffraction (XRDP) and scanning electron microscopy (SEM). The crystal structure of $\mathrm{Pb}_{2}\left[\mathrm{Fe}(\mathrm{CN})_{6}\right] .4 \mathrm{H}_{2} \mathrm{O}$ has been refined by Rietveld analysis using X- ray powder diffraction data. It Crystallizes in the monoclinic system with space group $\mathrm{P} 2_{1} / \mathrm{m}$ and the cell unit parameters are $\mathrm{a}=10.9755(2) \AA, \mathrm{b}=7.6285(1) \AA, \mathrm{c}=8.5696(1) \AA$ y $\beta=98.8375(9)^{\circ}$.

$\mathrm{Pb}_{2} \mathrm{Fe}_{2} \mathrm{O}_{5}$ has been obtained by a simple method, the thermal decomposition of $\mathrm{Pb}_{2}\left[\mathrm{Fe}(\mathrm{CN})_{6}\right] .4 \mathrm{H}_{2} \mathrm{O}$ at $700{ }^{\circ} \mathrm{C}$ in air. $\mathrm{Pb}_{2} \mathrm{Fe}_{2} \mathrm{O}_{5}$ crystallizes in the tetragonal system with cell unit parameters $\mathrm{a}=\mathrm{b}=7.80 \AA, \mathrm{c}=15.82 \AA$. $\mathrm{PbO}$ is also obtained.
\end{abstract}

Keywords: Thermal decomposition, $\mathrm{Pb}_{2}\left[\mathrm{Fe}(\mathrm{CN})_{6}\right] \cdot 4 \mathrm{H}_{2} \mathrm{O}, \mathrm{Pb}_{2} \mathrm{Fe}_{2} \mathrm{O}_{5}$, crystal structure, low temperature synthesis.

\section{INTRODUCTION}

The synthesis of mixed oxides, particullary brownmillerites, perovskites and related oxides from the decomposition of inorganic coordination compounds allows to lower the synthesis temperature down to the range 600 $-900{ }^{\circ} \mathrm{C}$ (well below the usual temperatures used in the conventional ceramic methods) and to obtain more homogeneous and finely divided powders ${ }^{1,2}$

$\mathrm{ABO}_{3-\delta}$ perovskite type oxides $(0 £ \delta £ 0.5, \mathrm{~A}=$ Lanthanide or alkaline earth, $\mathrm{B}=$ transition metal) have a great technological interest due to their electrical, magnetic and catalytic properties. They have been extensively used as catalyst in redox reactions, as in the reduction of nitrogen oxides and $\mathrm{SO}_{2}$, hydrogenation of hydrocarbons and in the elimination of atmospheric pollution. In the specific case of $\mathrm{A}=$ lanthanum, its oxides are particular suitable for applications as a material for sensors, for the detection of vapors and gases such as humidity, alcohol, oxygen, hydrocarbons, $\mathrm{CO}$ and $\mathrm{NO}_{2}{ }^{3-5}$. Pecchi et al. prepared $\mathrm{LaFeO}_{3}$ with different procedures and they compared them as catalysts for methane oxidation ${ }^{6}$. On the other hand, Bouyssières et al. replaced partially $\mathrm{La}$ in the lattice by $\mathrm{Ca}, \mathrm{Sr}$ or $\mathrm{Ba}$ and they studied the variation of surface area and its possible catalytic activity for $\mathrm{CO}$ oxidation?

In $\mathrm{AFeO}_{3-\delta}$ oxides, iron can be in the states $3+$ or $4+$. In these compounds, in which iron is in $4+$ oxidation state, many oxygen vacancies are usually generated $^{8-12}$ due to the high instability of $\mathrm{Fe}$ (IV). When $\delta=0.5$ all the iron is in oxidation state $3+$ and a brownmillerite type compound is formed ${ }^{9}$.

$\mathrm{ABO}_{3-8}$ perovskites containing an easily polarizable A cation with a sterically active lone electron pair $\left(\mathrm{Bi}^{3+}, \mathrm{Pb}^{2+}\right)$ and mostly covalent bonding to oxygen and a magnetically active transition metal $\mathrm{B}$ cation are attracting considerable attention nowadays due to expectations of finding new multiferroics materials. Multiferroics are materials that are (anti) ferromagnetically ordered, being at the same time in a ferroelectric state. The coupling between the electric and magnetic polarization, i.e., the magnetoelectric effect, imparts great value to such materials for practical applications due the possibility to controlling the magnetic polarization by an electric field and vice versa ${ }^{13}$.

$\mathrm{Pb}_{2} \mathrm{Fe}_{2} \mathrm{O}_{5}$ is expected to be an anion deficient perovskite of the brownmillerite type. However, its structure has not yet been determined because it has a large variety of crystallographic shear ${ }^{14}$.

In this paper we propose the synthesis of $\mathrm{Pb}_{2} \mathrm{Fe}_{2} \mathrm{O}_{5}$ obtained by a very simple method, the thermal oxidative decomposition of $\mathrm{Pb}_{2}\left[\mathrm{Fe}(\mathrm{CN})_{6}\right] .4 \mathrm{H}_{2} \mathrm{O}$ at low temperature. The decomposition process was followed by IR spectroscopy, thermogravimetric analysis (TGA), differential thermal analysis (DTA), laboratory $\mathrm{X}$ - ray powder diffraction (XRPD) and scanning electron microscopy (SEM).

\section{EXPERIMENTAL}

$\mathrm{Pb}_{2}\left[\mathrm{Fe}(\mathrm{CN})_{6}\right] \cdot 4 \mathrm{H}_{2} \mathrm{O}$ was prepared by mixing equal volumes of $0.1 \mathrm{M}$ $\mathrm{K}_{4}\left[\mathrm{Fe}(\mathrm{CN})_{6}\right]$ and $0.2 \mathrm{M} \mathrm{Pb}\left(\mathrm{NO}_{3}\right)_{2}$ solutions and stirred for two hours. The white precipitate formed was separated by filtration and washed several times with distilled water and finaly stored in a dry box with silica gel.

The thermal decomposition behavior of the complex was studied by thermogravimetric and differential thermal analysis (TGA/DTA). TGA and DTA were performed in a Termogravimetric and Differential Thermal Analyzer Shimadzu TGA/DTA-50 at $5 \%$ min under flowing air.

Based in TGA results, the sample was heated in air flow in a furnace at different temperatures for 6 hours in order to obtain $\mathrm{Pb}_{2} \mathrm{Fe}_{2} \mathrm{O}_{5}$.

IR spectra were recorded with a FTIR Perkin Elmer 1600 in the transmission mode using $\mathrm{KBr}$ pellets.

Laboratory powder XRD pattern for the samples was taken in a Philips PW1710 diffractometer, with $\mathrm{Cu} K \alpha$ radiation $(\lambda=1.5418 \AA)$ between $5^{\circ}$ and $90^{\circ}$ in $2 \theta$, steps of $0.02^{\circ}$. The structure refinement of $\mathrm{Pb}_{2}\left[\mathrm{Fe}(\mathrm{CN})_{6}\right] .4 \mathrm{H}_{2} \mathrm{O}$ was performed by Rietveld Method using the FULLPROF program with laboratory powder XRD data, in the space group $\mathrm{P} 2 / \mathrm{m}^{15}$.

The size and morfology of the particles were determinated by scanning electron microscopy (SEM) with a JEOL JSM 35 CF.

\section{RESULTS AND DISCUSSION}

\section{$3.1 \mathrm{~Pb}_{2}\left[\mathrm{Fe}(\mathrm{CN})_{6}\right] .4 \mathrm{H}_{2} \mathrm{O}$}

3.1.1 IR spectra

In order to characterize the complex and their thermal decomposition products, IR spectra were recorded in transmission mode. Fig.1 shows the IR spectra for the complex $\mathrm{Pb}_{2}\left[\mathrm{Fe}(\mathrm{CN})_{6}\right] .4 \mathrm{H}_{2} \mathrm{O}$. The IR spectra of hexacyanometallates are composed of three vibrations within the octahedral unit $\mathrm{M}(\mathrm{CN})_{6}: v(\mathrm{CN}), \delta(\mathrm{MCN})$ and $v(\mathrm{MC})$; and those motions from crystal water, $v(\mathrm{OH})$ and $\delta(\mathrm{HOH})$, when it is present ${ }^{16}$. For $\mathrm{Pb}_{2}\left[\mathrm{Fe}(\mathrm{CN})_{6}\right] .4 \mathrm{H}_{2} \mathrm{O}$, the $v(\mathrm{CN})$ stretching band is observed at $2041 \mathrm{~cm}^{-1}$. For the bending vibrations of water at least three bands are well resolved. The highest frequency band in the $\delta(\mathrm{HOH})$ vibrations region, at $1646 \mathrm{~cm}^{-1}$, corresponds to the weakly bonded waters, the intermediate one at $1619 \mathrm{~cm}^{-1}$ also belongs to coordinated water molecules but with a weaker coordination bond and the band at $1597 \mathrm{~cm}^{-1}$ is attributed to those water molecules with the stronger interaction with the metal ${ }^{17}$. In the $v(\mathrm{OH})$ vibrations region at $3500 \mathrm{~cm}^{-1}$ four bands are observed that corresponds to coordinated water molecules. 


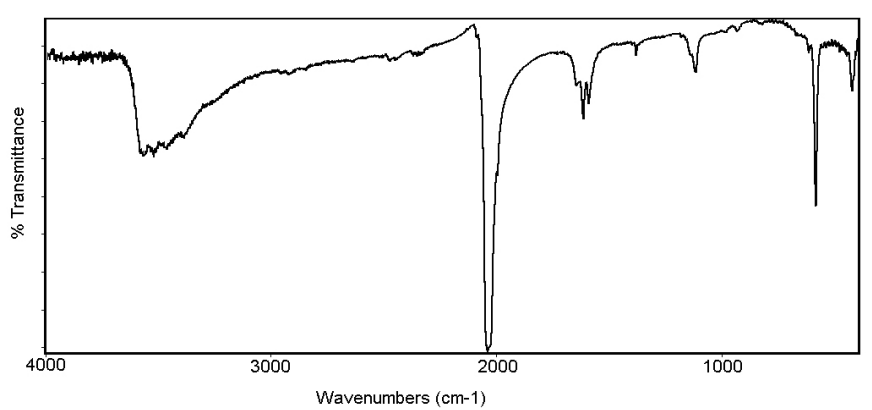

Figure 1. IR spectrum for $\mathrm{Pb}_{2}\left[\mathrm{Fe}(\mathrm{CN})_{6}\right] \cdot 4 \mathrm{H}_{2} \mathrm{O}$. data

3.1.2 Thermogravimetic (TGA) and differential thermal analysis (DTA)

TGA and DTA data for $\mathrm{Pb}_{2}\left[\mathrm{Fe}(\mathrm{CN})_{6}\right] .4 \mathrm{H}_{2} \mathrm{O}$ are shown in Fig. 2 and 3. Three main steps are observed in TGA for the decomposition process in air. The first one ends at $98^{\circ} \mathrm{C}$, with a mass loss of $10.05 \%$, due to the dehydration process to obtain the anhidrous complex (theoretical value $10.31 \%$ ). This corresponds to an endothermic process observed in DTA at $87^{\circ} \mathrm{C}$. The second step in TGA finishes at $385^{\circ} \mathrm{C}$ approximately and it has a mass loss of $14.23 \%$. This mass loss was attributed to liberation of $\mathrm{CN}$ groups that in DTA corresponds to a very exothermic peak at $373{ }^{\circ} \mathrm{C}$. At temperatures above $500{ }^{\circ} \mathrm{C}$ the mass loss remained constant. The total mass loss was $24.28 \%$, which agrees with the theoretical loss $\left(24.64 \%\right.$ ) calculated for the formation of $\mathrm{Pb}_{2} \mathrm{Fe}_{2} \mathrm{O}_{5}$ and $\mathrm{PbO}$. The corresponding chemical reaction (partial) could be represented as: $\mathrm{O}_{2}$

$2 \mathrm{~Pb}_{2}\left[\mathrm{Fe}(\mathrm{CN})_{6}\right] .4 \mathrm{HO}_{2} \rightarrow \mathrm{Pb}_{2} \mathrm{Fe}_{2} \mathrm{O}_{5}+2 \mathrm{PbO}+$ volatile products

We will not speculate about the decomposition mechanism because this is not the objective of this paper.

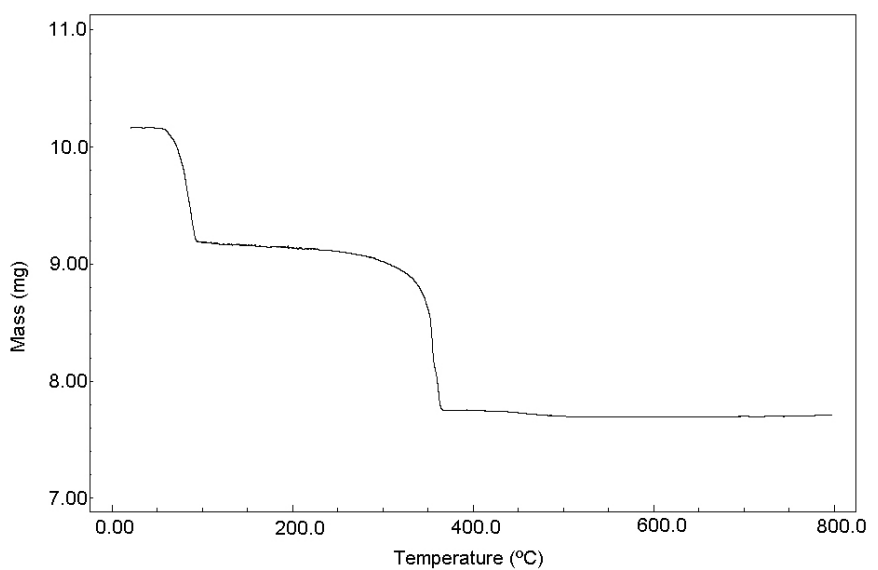

Figure 2. TGA data for $\mathrm{Pb}_{2}\left[\mathrm{Fe}(\mathrm{CN})_{6}\right] .4 \mathrm{H}_{2} \mathrm{O}$ at $5 \%$ min in air.

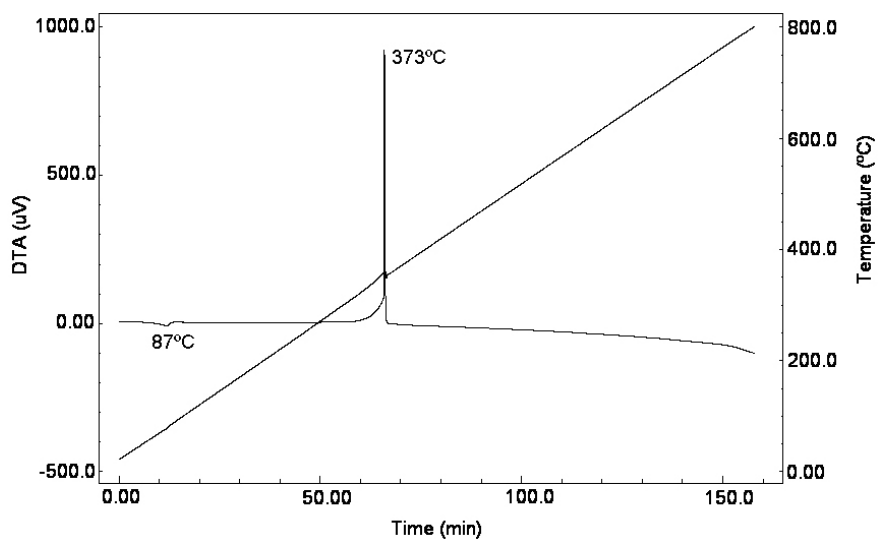

Figure 3. DTA data for $\mathrm{Pb}_{2}\left[\mathrm{Fe}(\mathrm{CN})_{6}\right] .4 \mathrm{H}_{2} \mathrm{O}$ at $5 \% \mathrm{~min}$ in air.

3.1.3 Powder X-ray Diffraction

The XRPD pattern of the synthesized complex fits well the PDF File No. 51-1785, corresponding to $\mathrm{Pb}_{2}\left[\mathrm{Fe}(\mathrm{CN})_{6}\right] \cdot 4 \mathrm{H}_{2} \mathrm{O}$, which crystalize in the monoclinic system. Fig. 4 shows the XDPR pattern refined in the space group $\mathrm{P} 2 / \mathrm{m}^{15}$.

In Table I the estimated cell parameters, cell volume per formula unit, space group are summarized.

Table I. Unit cell parameters, cell volume per formula unit and space group for $\mathrm{Pb}_{2}\left[\mathrm{Fe}(\mathrm{CN})_{6}\right] .4 \mathrm{H}_{2} \mathrm{O}$.

\begin{tabular}{|c|c|c|c|}
\hline Complex & Unit Cell Parameters $(\AA)$ & $\begin{array}{c}\text { Cell } \\
\text { volume } \\
\left(\AA^{3}\right)\end{array}$ & $\begin{array}{c}\text { Space } \\
\text { group }\end{array}$ \\
\hline & $\mathrm{a}=10.9755(2)$ & & \\
$\mathrm{b}=7.6285(1)$ & $708.98(2)$ & $\mathrm{P} 2_{1} / \mathrm{m}$ \\
$\mathrm{Pb}_{2}\left[\mathrm{Fe}(\mathrm{CN})_{6}\right] .4 \mathrm{H}_{2} \mathrm{O}$ & $\mathrm{c}=8.5696(1)$ & & \\
\hline
\end{tabular}

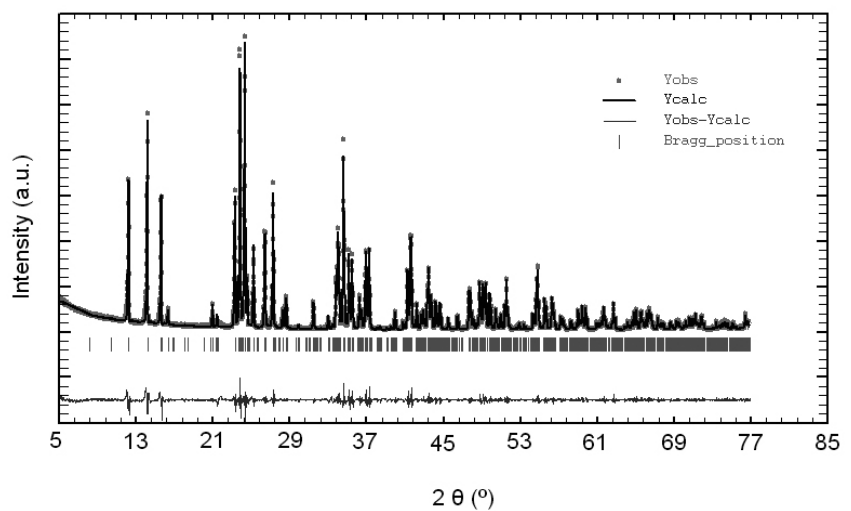

Figure 4. XDPR pattern of $\mathrm{Pb}_{2}\left[\mathrm{Fe}(\mathrm{CN})_{6}\right] .4 \mathrm{H}_{2} \mathrm{O}$ refined in the space group $\mathrm{P} 2 / \mathrm{m}$

3.2 Mixed oxides obtained by heat treatment of $\mathrm{Pb}_{2}\left[\mathrm{Fe}(\mathrm{CN})_{6}\right] .4 \mathrm{H}_{2} \mathrm{O}$ at different temperatures

3.2.1. IR spectra

IR spectra obtained of the samples heated at different temperatures are shown in Fig. 5. The $v(\mathrm{CN})$ stretching band disappeared when the complex was heated to $500{ }^{\circ} \mathrm{C}$, and bands attributable to carbonate groups in the 1100 $1500 \mathrm{~cm}^{-1}$ region began to appear. When the complex was heated to $650{ }^{\circ} \mathrm{C}$, the bands corresponding to carbonate groups disappeared and only a strong band for the stretching M-O typical of the oxides was observed at $561 \mathrm{~cm}^{-1}$. This situation did not change at the temperaures higher than $650^{\circ} \mathrm{C}^{16}$.

The broad band observed in the $3100-3700 \mathrm{~cm}^{-1}$ range in all the samples is attributed to surface-adsorbed $-\mathrm{OH}$ species ${ }^{1}$.

The presence of carbonates on the samples is attributed to their exposure 
to ambient air at room temperature after cooling. This is in agreement with the studies of Traversa et al. in the sense that the surface of particles obtained by thermal decomposition of some hexacyanoferrates are very active to chemisorption of $\mathrm{CO}_{2}$ and the consequent carbonate formation on the surface ${ }^{18,19}$.

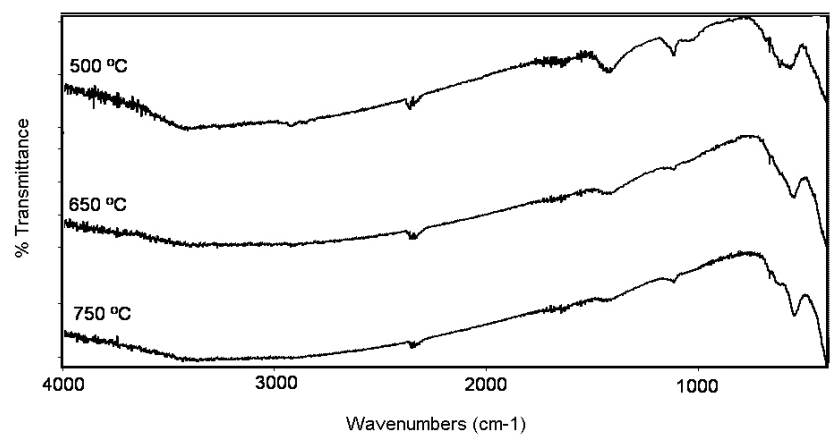

Figure 5. IR spectra for $\mathrm{Pb}_{2} \mathrm{Fe}_{2} \mathrm{O}_{5}$ obtained by thermal decomposition in air of $\mathrm{Pb}_{2}\left[\mathrm{Fe}(\mathrm{CN})_{6}\right] \cdot 4 \mathrm{H}_{2} \mathrm{O}$ for 6 hours at different temperatures.

\subsubsection{Powder XRD data}

The XRPD profiles of the decomposition products of $\mathrm{Pb}\left[\mathrm{Fe}(\mathrm{CN})_{6}\right] .4 \mathrm{H}_{2} \mathrm{O}$ at different temperatures are shown in the Fig. 6. When the complex was decomposed at $500{ }^{\circ} \mathrm{C}$, some peaks attributed to $\mathrm{Fe}_{2} \mathrm{O}^{20}$ and $\mathrm{PbO}^{21}$ are observed. When the complex was decomposed at temperatures higher $6500^{\circ} \mathrm{C}$, the XRPD analysis showed the pattern corresponding to $\mathrm{Pb}_{2} \mathrm{Fe}_{2} \mathrm{O}_{5}{ }_{5}^{22}$, which crystallizes in the Tetragonal system with $\mathrm{a}=\mathrm{b}=7.80 \AA \mathrm{c}=15.82 \AA$ and $\mathrm{PbO}^{21}$ which crystallizes in the orthorrombic crystal system, space group $\mathrm{Pbcm}$, cell parameters $\mathrm{a}=5.8760 \AA, \mathrm{b}=5.4760 \AA$ and $\mathrm{c}=4.7430 \AA . \mathrm{Pb}_{2} \mathrm{Fe}_{2} \mathrm{O}_{5}$ oxide was detected together with $\mathrm{PbO}$ because the ratio $\mathrm{Pb}: \mathrm{Fe}$ in the precursor complex was 2:1

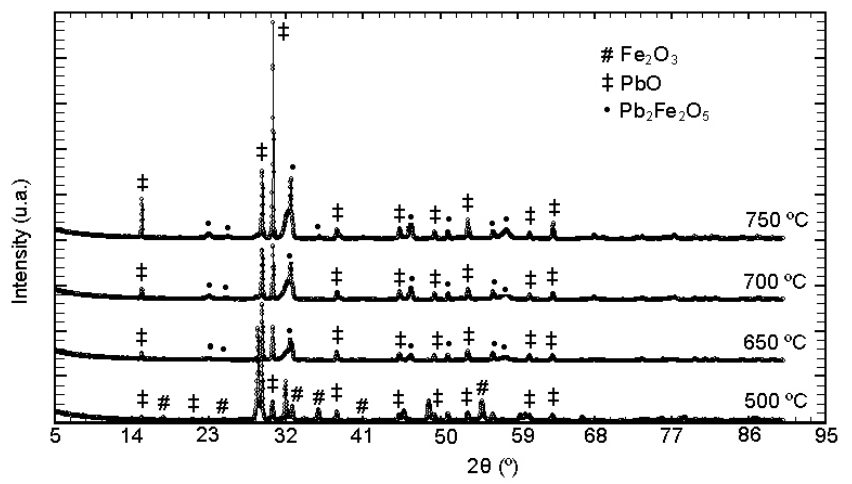

Figure 6. XRPD profiles of the decomposition products of $\mathrm{Pb}_{2}\left[\mathrm{Fe}(\mathrm{CN})_{6}\right] \cdot 4 \mathrm{H}_{2} \mathrm{O}$ at different temperatures.

\subsubsection{Scanning Electron Microscopy (SEM)}

Figure 7 shows the SEM photographs of $\mathrm{Pb}_{2}\left[\mathrm{Fe}(\mathrm{CN})_{6}\right] .4 \mathrm{H}_{2} \mathrm{O}$ and the decomposition product obtained in air at $700{ }^{\circ} \mathrm{C}$. For $\mathrm{Pb}_{2}\left[\mathrm{Fe}(\mathrm{CN})_{6}\right] \cdot 4 \mathrm{H}_{2} \mathrm{O}$ the average particle size is approximately $3 \mu \mathrm{m}$ (Fig. 7a). The size and well defined shapes of the crystals are similar to lanthanum hexacyanoferrates ${ }^{19}$. After decomposition at $700{ }^{\circ} \mathrm{C}$, the size of the crystals have reduced at about to the half (Fig. 7b) due to the evolution of gases during the decomposition process. In fact this method of synthesis produces relatively small particles that could have good catalytic properties ${ }^{9,23-25}$.

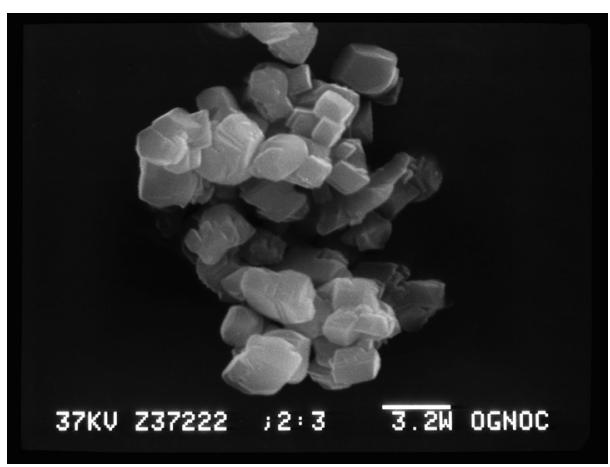

(a)

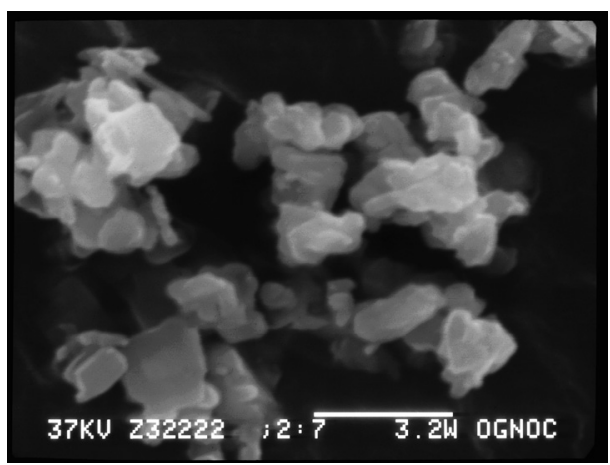

(b)

Figure 7. SEM images of: (a) $\mathrm{Pb}_{2}\left[\mathrm{Fe}(\mathrm{CN})_{6}\right] \cdot 4 \mathrm{H}_{2} \mathrm{O}$; (b) $\mathrm{Pb}_{2}\left[\mathrm{Fe}(\mathrm{CN})_{6}\right] \cdot 4 \mathrm{H}_{2} \mathrm{O}$ calcined at $700{ }^{\circ} \mathrm{C}$ for 6 hours in air.

\section{CONCLUSIONS}

$\mathrm{Pb}_{2} \mathrm{Fe}_{2} \mathrm{O}_{5}$ was obtained at $700^{\circ} \mathrm{C}$ by thermal decomposition of the inorganic complex $\mathrm{Pb}_{2}\left[\mathrm{Fe}(\mathrm{CN})_{6}\right] .4 \mathrm{H}_{2} \mathrm{O}$. The complex and the decomposition products were characterized by thermal analysis (TGA and DTA), IR spectroscopy (FTIR) and powder X-ray diffraction (XPRD). The thermal decomposition ocurrs via two stages resulting $\mathrm{Pb}_{2} \mathrm{Fe}_{2} \mathrm{O}_{5}$ and $\mathrm{PbO}$ as final products. $\mathrm{Pb}_{2} \mathrm{Fe}_{2} \mathrm{O}_{5}$ crystallizes in the tetragonal system with $\mathrm{a}=\mathrm{b}=7.80 \AA, \mathrm{c}=15.82 \AA$. PbO was indexed with the space group $P b c m$ and the unit cell parameters $\mathrm{a}=5.8760 \AA$, $\mathrm{b}=5.4760 \AA$ and $\mathrm{c}=4.7430 \AA$

The size of the particles of the oxides are relatively small and it could be used with promising applications in catalysis.

\section{ACKNOWLEDGEMENT}

R. E. C. Thanks ANPCYT for PICT 06-15102, CONICET for PIP $5767 / 05$ and SECyT-UNC for Proyect 197/05. D.M.G. Thanks CONICET for fellowships. D.M.G. and M.I.G. Thank CIUNT for financial support.

\section{REFERENCES}

[1] M. C. Navarro, E. V. Pannunzio Miner, S. Pagola, M. I. Gómez and R. E. Carbonio, J. Solid State chem. 178, 847, (2005).

[2] S. Nakayama, M. Sakamoto, K. Matsuki, Y. Okimura, R. Ohsumi, Y. Nakayama and Y. Sadaoka, Chem. Lett. 2145, (1992).

[3] S. Nakayama and M. Sakamoto, J. Ceram. Soc. Japan. 100, 354, (1992).

[4] J. P. Lukaszewicz, Sensors and Actuators B, 4, 227, (1991).

[5] Y. Matsuura, S. Matsushima, M. Sakamoto and Y. Sadaoka, J. Matter. Chem. 3, 767, (1993).

[6] G. Pecchi, P. Reyes, R. Zamora, L. Cadús, B. Barbero, J. Chil. Chem. Soc. 51(4), 1001, (2006).

[7] L. Bouyssiéres, R. Schifferli, L. Urbina, P. Araya, J. M. Palacios, J. Chil. Chem. Soc. 50(1), 407, (2005).

[8] E. Traversa, S. Matsushima, G. Okada, Y. Sadaoka, Y. Sakai and K. Watanabe, Sensors and Actuators B, 25, 661, (1995). 
[9] M. I. Gómez, J. A. de Moran, P. J. Aymonino, S. Pagola, P. Stephens and R. E. Carbonio, J. Solid State chem. 17, 160, (2001).

[10] M. I. Gómez, J. A. de Moran, R. E. Carbonio and P. J. Aymonino, J. Solid State chem. 142, 138, (1999).

[11] Y. Takeda, K. Kanno, T. Takada, O. Yamamoto, M. Takano, N. Nakayama, Y. Bando, J. Solid State Chem. 63, 237, (1986).

[12] M. Takano, Y. Takeda, Bull. Inst. Chem. Res. Kyoto Univ. 5, 61, (1983).

[13] A. M. Abakumov, J. Hadermann, G. Van Tendeloo and E. V. Antipov, $J$. Am. Ceram. Soc. 91, 1807, (2008).

[14] A. M. Abakumov, J. Hadermann, S. Bals, I. V. Nikolaev, E. V. Antipov and G. Van Tendeloo, Angew. Chem. Int. Ed. 45, 6667. (2006).

[15] Powder Diffraction Files, JCPDS-ICDD File 51-1785, (2000).

[16] K. Nakamoto. Infrared and Raman Spectra of Inorganic and Coordination Compounds, John Wiley \& Sons, New York, United State of America (1997).
[17] M. Avila, L. Reguera, J. Rodriguez Hernandez, J. Balmaseda, E. Reguera, J. Solid State Chem. 181, 2899, (2008).

[18] E. Traversa, P. Nunziante, M. Sakamoto, Y. Sadaoka, R. Montanari, Matter. Res. Bull. 33, 673, (1998).

[19] E. Traversa, P. Nunziante, M. Sakamoto, Y. Sadaoka, M. Carotta and G. Martinelli, J. Mater. Res. 13, 5, (1998).

[20] Powder Diffraction Files, JCPDS-ICDD File No 40-1139, (1986).

[21] Powder Diffraction Files, JCPDS-ICDD File No 01-072-0093, (1997).

[22] Powder Diffraction Files, JCPDS-ICDD File No 33-0756, (1978).

[23] L. M. Córdoba, M. I. Gómez, J. A. de Moran and P. J. Aymonino, J. Argent. Chem. Soc. 96, 1-2, 1, (2008).

[24] H. He, H. X. Dai, C.T. Au, Appl. Catal. B: environmental. 33, 65 (2001).

[25] M. Tomoda, S. Okano, Y. Itagaki, H. Aono, Y. Sadaoka, Sensors Actuactors B. 9, 190 (2004). 